\title{
ACHIEVEMENTS AND BOTTLENECKS IN DEVELOPING SUNFLOWER HYBRIDS FOR UGANDA
}

\author{
Anyanga, W.O. \\ Serere Agricultural and Animal Production Research Institute (SAARI), P.O. Soroti, \\ Uganda.
}

Received: October 10, 2006

Accepted: May 15, 2007

SUMMARY

Sunflower (Helianthus annuus L.) has become the most important oil crops in Uganda. The area under production has increased dramatically since the mid 1990s. In the 1970s and 1980s, sunflower breeding research was based on evaluating imported hybrids. This did not show any impact in commercial production. Recent evaluation of hybrids led to the release of PAN 7351 from South Africa which is now in full production and being imported by Mukwano Seed Company. Serere Agricultural Research Institute (SAARI) received a few hybrid parental lines for hybrid development. Some bottlenecks like branching and fertility of female lines led to slow development of hybrids from these parental lines. A few crosses have been made and yields of over $2,000 \mathrm{~kg} / \mathrm{ha}$ have been attained. Uganda is now in position to produce her own hybrid seed.

Key words: sunflower, agronomic practices, seed yield, oil content, hybrid development

\section{INTRODUCTION}

Sunflower (Helianthus annuus L.) has become the most important oil crops in Uganda especially in the eastern and northern parts of the country. The area under production had increased from the mid 1990s till the present. This is partly due to the number of potential oil mills installed in areas where sunflower is intensively grown and the market is ready. For example, in Lira district, there are over 26 oil mills.

Despite the increasing production of sunflower in the country, the yield remained low at farmers' level. The main factors that have caused low yields in the country are lack of high yielding varieties/hybrids and poor agronomic practices. The average yield in farmers' fields is about $750-900 \mathrm{~kg} / \mathrm{ha}$ and yields of the best open-pollinated varieties at the Institute are about 1,500-1,800 kg/ha.

* Corresponding author: E-mail: walanyanga@hotmail.com 
Not a single sunflower hybrid has been developed in Uganda although sunflower research started as early as 1960/70s. The first imported hybrid to be officially released was PAN 7351 in 2003. This hybrid was developed by PANNAR Seed Company in South Africa. Before this, the leader in the commercial production was an open pollinated variety called "Sunfola", which originated from Australia and which was released in Uganda in 1991 under the USAID underproject (1988-1993).

The main aim of sunflower breeding program is to increase seed yield and oil content and to develop varieties resistant to the prevailing diseases. Much emphasis is presently placed on hybrid development. According to Fick (1975), single cross hybrids give $20-30 \%$ higher yield than the varietal populations. Giriraj (1998) also observed that one of the approaches for increasing productivity of sunflower is to cultivate high yielding hybrid cultivars replacing low yielding open pollinated varieties. The main advantages of introducing hybrids into production are utilization of heterosis, uniformity of the $\mathrm{F} 1$ generation, and easier incorporation of resistance to diseases and other desirable traits.

One of the most effective ways of increasing the yield of sunflower per unit area is the usage of heterosis through single-cross hybrids. To develop single-cross hybrids with high genetic potential for yield and other agronomic characters, it is essential to have inbred lines with high values of combining ability. Sunflower hybrid breeding is based on cytoplasmic male sterility ( $\mathrm{cms}$ ), its maintainer (B-line) and restorer line. Emphasis is placed on single- and three-way crosses.

The objective of this paper is to give a long-term overview of the dynamics of sunflower hybrid evaluation and development of sunflower research in Uganda.

\section{MATERIALS AND METHODS}

In the 1970s and early 1980s, sunflower hybrids imported from other countries were tested Serere Research Station based in the eastern part of Uganda. Since these materials were already developed hybrids and not parental lines that produce a hybrid, it was possible only to evaluate these hybrids but we could not make our own hybrids.

In the period 1987-1989, the insurgence raged in a greater part of eastern and northern Uganda in which most of the germplasm of Serere Research Station was either lost or destroyed.

In 1988, the USAID funded a project on sunflower research at Namulonge Research Station. The breeding program at Namulonge comprised basically the testing of hybrids imported from USA. Three parental inbred lines: cmsHA89, HA89 and HA82 1 (maintainers or B-lines), RHA271 (restorer line) were imported in bulk from USA for commercial seed production. Hybrid seed was produced from these lines. As the project came to an end in 1993, that was the end of hybrid parental line evaluation and hybrid production since reliance was on the imported seed only. 
From 1994 to 1997 sunflower research was limited. NARO supported research for only 2 years and then stopped the funding. The Vegetable Oil Development Project (VODP) under the Ministry of Agriculture, Animal Industry and Fisheries concentrated on adaptive research and showed little interest in breeding. The breeding program was very slow and in some seasons, no work at all has been done. Whenever the funding flagged, a bottleneck would occur. New germplasm had to be assembled from the beginning. This time, new germplasm was collected at Serere as the work in Namulonge came to an end.

In the year 2000, collaboration started afresh between Serere Agricultural Research Institute (SAARI), Uganda's Investment in Developing Export Agriculture Project (IDEA) and PANNAR Seed Company in South Africa, to evaluate hybrids from this seed company. Out of the seven PANNAR hybrids tested against some open-pollinated varieties in 2001 (Table 1), the hybrid PAN7351 was officially released in 2003 and it is being imported by Mukwano Seed Company. It is sold to Uganda farmers at the price of about 4 US\$ (7,000 Uganda Shillings) for one kilogram of hybrid seed. This is quite expensive for the resource-poor farmers in Uganda.

During 2000-2002, hybrid parental lines were acquired from United States Department of Agriculture (USDA) facility at Fargo, North Dakota. Some of these new lines were found to be producing pollen in the female rows and some exhibited also the branching habit. Due to inadequate knowledge in maintaining line purity of these materials, the branching habit and pollen shedding among these lines increased. This was a blow to our breeding program. Sometimes new lines when planted for the first time also showed pollen fertility and branching in female lines, which meant that the problem occurred where the line was developed. These problems arose due to the fact that, sometimes, the parental lines sent to you are not sufficiently pure. Another possibility is that the problems occurred due to modifier genes coming to expression as a result of environmental effects. The half-sib mating method was used. For pollination, pollen was collected from all maintainers and bulked. The problem comes if one or more of those maintainer plants possess restoration genes which, after pollinating the female plants, produce progenies that are fertile. This means that the breeding material has been contaminated somewhere during the breeding procedure, either through outcrossing or seed mingling.

In 2003-2004, another approach was tried, through full sib mating or pair-wise mating of the maintainer and the female lines. Here, a particular maintainer plant is crossed to a particular female plant and three to five pairs per parental line are crossed and then the progenies monitored to observe whether there is pollen production among the female plants. If pollen production is observed in the progenies, either these plants are discarded or screening and selection continues until pure male sterile progenies are observed. 


\section{RESULTS AND DISCUSSION}

Table 1 shows the performance of the hybrids imported from PANNER Seed Company in South Africa compared with some open-pollinated varieties. The best hybrids were PAN7351 and PAN7371. PAN7351 was officially released in 2003 and, from 2004 to 2006, over 100 metric tons were imported annually by Mukwano Seed Company.

Table 1: Yield performance of sunflower hybrids from South African Pannar Seed Company and other open-pollinated varieties in five centres in Uganda during 2001

\begin{tabular}{|c|c|c|c|c|c|c|c|}
\hline & Entry & $\begin{array}{l}\text { Serere } \\
2001 A\end{array}$ & $\begin{array}{c}\text { Kumi } \\
2001 B\end{array}$ & Aduku $2001 \mathrm{E}$ & Kuju 2001B & $\begin{array}{l}\text { Ngetta } \\
\text { 2001B }\end{array}$ & Mean \\
\hline 1 & 7351 & $1982(3)$ & $1456(5)$ & $1284(1)$ & $1667(1)$ & $1853(1)$ & $1648(1)$ \\
\hline 2 & 7355 & $1783(7)$ & $1407(6)$ & $703(8)$ & $1120(7)$ & $847(10)$ & $1172(7)$ \\
\hline 3 & 7371 & $1886(5)$ & $1485(3)$ & 1095(2) & 1472(2) & $1620(2)$ & $1512(2)$ \\
\hline 4 & 7392 & $1839(6)$ & $1634(1)$ & $849(4)$ & $1464(3)$ & $1591(4)$ & $1475(4)$ \\
\hline 5 & 7001 & 2038(2) & $1406(7)$ & $982(3)$ & $1337(5)$ & $1543(6)$ & $1461(5)$ \\
\hline 6 & 7352 & $2072(1)$ & 1553(2) & $756(5)$ & $1454(4)$ & 1592(3) & $1485(3)$ \\
\hline 7 & 7353 & $1916(4)$ & $1482(4)$ & $747(6)$ & $1132(6)$ & $1587(5)$ & $1373(6)$ \\
\hline 8 & Local Stripe & - & - & $538(10)$ & $1057(9)$ & $1191(8)$ & $929(11)$ \\
\hline 9 & Sunfola & 1578(8) & 1188(8) & $719(7)$ & $969(10)$ & $1247(7)$ & $1140(8)$ \\
\hline 10 & Record Romania & $1260(10)$ & - & $632(9)$ & $812(11)$ & - & $901(12)$ \\
\hline 11 & Kolos & $1262(9)$ & $1000(10)$ & $509(11)$ & $1103(8)$ & $969(9)$ & $969(10)$ \\
\hline \multirow[t]{5}{*}{12} & Saluit Serere & - & $1065(9)$ & - & - & - & $1065(9)$ \\
\hline & Mean & 1762 & 1368(9) & 801 & 1235 & 1404 & 1314 \\
\hline & CV & 20 & 16.6 & 42 & 18.5 & 21 & \\
\hline & SED & NS & 184.8 & 276.6 & 187 & 247 & \\
\hline & LSD & NS & * & NS & $\star \star \star$ & $\star \star$ & \\
\hline
\end{tabular}

NB. * $A$ and $B$ are first and second rainy seasons, respectively.

Table 2: Evaluation of Serere crossed hybrids during second rains of 2003

\begin{tabular}{|c|c|c|c|c|c|c|c|c|}
\hline & Lines & $\begin{array}{l}\text { Yield } \\
\mathrm{kg} / \mathrm{ha}\end{array}$ & Rank & $\begin{array}{l}\text { No } \\
\text { heads/ } \\
\text { plot }\end{array}$ & $\begin{array}{l}\text { Days } \\
50 \% \\
\text { flowering }\end{array}$ & $\begin{array}{l}\text { Days } \\
\text { maturi- } \\
\text { ty }\end{array}$ & $\begin{array}{l}1000 \\
\text { seed } \\
\text { weight }\end{array}$ & $\begin{array}{l}\text { Head } \\
\text { diame- } \\
\text { ter } \\
(\mathrm{cm})\end{array}$ \\
\hline 1. & $c m s$ HA371-2A $\times$ RHA271-1-1 & 1594 & 5 & 12 & 59 & 98 & 76 & 23 \\
\hline 2. & $c m s$ HA371-2A $\times$ RHA271-1-3 & 1700 & 3 & 11 & 61 & 100 & 79 & 24 \\
\hline 3. & $c m s$ HA371-1A $\times$ RHA271-1-1 & 1033 & 8 & 11 & 60 & 96 & 78 & 23 \\
\hline 4. & cms HA89-2A × R632-2 & 1672 & 4 & 13 & 60 & 98 & 77 & 22 \\
\hline 5. & cms HA89-2A $\times$ R632-3 & 2021 & 2 & 13 & 61 & 100 & 67 & 25 \\
\hline 6. & cms HA89-1A $\times$ R632-3 & 1251 & 7 & 8 & 64 & 101 & 69 & 23 \\
\hline 7. & cms HA89-1A $\times$ R632-1 & 2195 & 1 & 12 & 62 & 101 & 72 & 27 \\
\hline \multirow[t]{5}{*}{8.} & Sunfola & 1282 & 6 & 10 & 62 & 100 & 76 & 23 \\
\hline & Mean & 1594 & & 11 & 61 & 99 & 74 & 24 \\
\hline & CV\% & 38 & & 44.9 & 2.5 & 1.3 & 10.8 & 10.4 \\
\hline & SED & 504.8 & & 4.1 & 1.2 & 1.0 & 6.5 & 2.0 \\
\hline & LSD & NS & & NS & * & & NS & NS \\
\hline
\end{tabular}


The first crossing program to produce single-cross hybrids was performed in the first rainy season of 2003 where some of the purified female lines were crossed to a few restorers. During the second rainy season of 2003 (Table 2), the hybrids were planted at Serere Agricultural Research Institute to observe their performance and find whether we were on the right track to start producing hybrids. Table 2 shows that yields of over $2,000 \mathrm{~kg} /$ ha were recorded. One hybrid performed well but it had so many branches which meant that there was still a problem with one of the parental lines when it was being crossed.

From 2004, most parental lines were observed to be pure with a few that showed pollen fertility and branching habit, which are not desirable characters in sunflower hybrids production. These problems was also observed and reported by Muralidharan (1998). New lines were again requested from USDA (USA) and these are presently being maintained using full-sib or pair-wise method and observing their progenies for pollen fertility. This procedure for the maintenance of parental lines was also published by Virupakshappa et al., 1998. During the first rainy season of 2005, over 320 hybrids were made by crossing 80 female lines with 4 restorers viz: RHA271, RHA373, CM632 and R694. A few were evaluated in a replicated trial as seen in Table 3 and 4.

Table 3: Evaluation of sunflower hybrids at SAARI during 2005A

\begin{tabular}{|c|c|c|c|}
\hline & Treatment & Yield, kg/ha & Rank \\
\hline 1. & cms 89-1A-1 $\times$ RHA271 & 1733 & 11 \\
\hline 2. & $c m s$ 371-1A × R694 & 1933 & 9 \\
\hline 3. & cms 371-1A × CM632 & 2083 & 3 \\
\hline 4. & cms 371-2A-1 × CM632 & 1692 & 14 \\
\hline 5. & DK 4040 & 1650 & 17 \\
\hline 6. & $c m s$ 371-2A-1 $\times$ RHA271 & 1667 & 16 \\
\hline 7. & $c m s$ 371-2A-2 × RHA271 & 2275 & 1 \\
\hline 8. & SUNFOLA & 2025 & 6 \\
\hline 9. & $c m s$ 371-2A-2 × CM632 & 1833 & 10 \\
\hline 10. & cms 371-21-3 × R694 & 1708 & 13 \\
\hline 11. & cms 371-3A $\times$ RHA271 & 1608 & 19 \\
\hline 12. & PAN7351 & 1567 & 20 \\
\hline 13. & cms 372-1A × CM632 & 2083 & 3 \\
\hline 14. & cms 372-2A $\times$ CM632 & 1983 & 8 \\
\hline 15. & cms 372-1A × R694 & 2275 & 1 \\
\hline 16. & DKF 68-22 & 1650 & 17 \\
\hline 17. & cms 412-1A-2 × R694 & 1692 & 14 \\
\hline 18. & cms 412-1A-2 × CM632 & 1733 & 11 \\
\hline 19. & cms 412-1A-2 × RHA271 & 2025 & 6 \\
\hline \multirow[t]{2}{*}{20.} & cms 412-2A-1 $\times$ RHA271 & 2042 & 5 \\
\hline & Mean & 1863 & \\
\hline
\end{tabular}


Yields of over $2,000 \mathrm{~kg} /$ ha were recorded among some hybrids developed at Serere. According to Škorić and Jocić (2004), they test over 3,000 new experimental hybrids each year and therefore our number of tested hybrids is still modest.

Table 4: Evaluation of sunflower hybrids at SAARI during 2005A

\begin{tabular}{|c|c|c|c|}
\hline & Treatment & Yield, kg/ha & Rank \\
\hline 1. & 89-1A-1 × CM632 & 1583 & 8 \\
\hline 2. & $371-2 \mathrm{~A} \times \mathrm{R} 694$ & 1217 & 17 \\
\hline 3. & $371-2 A \times R 694$ & 1717 & 4 \\
\hline 4. & $371-21-2 \times \mathrm{R} 694$ & 1217 & 17 \\
\hline 5. & $37-2 \mathrm{~A}-3 \times \mathrm{CM} 632$ & 1417 & 12 \\
\hline 6. & DK 4040 & 2167 & 2 \\
\hline 7. & $372-1 \mathrm{~A} \times \mathrm{RHA} 271$ & 917 & 29 \\
\hline 8. & $372-2 \mathrm{~A} \times \mathrm{RHA} 271$ & 1133 & 20 \\
\hline 9. & $372-2 A \times R 694$ & 1050 & 24 \\
\hline 10. & DKF 68-22 & 1717 & 4 \\
\hline 11. & $403-1 \mathrm{~A}-2 \times \mathrm{R} 694$ & 1333 & 13 \\
\hline 12. & $412-5 \mathrm{~A}-1 \times \mathrm{R} 694$ & 1633 & 7 \\
\hline 13. & $412-4 A-4 \times R 694$ & 2417 & 1 \\
\hline 14. & $412-6 \mathrm{~A}-1 \times \mathrm{R} 694$ & 1050 & 24 \\
\hline 15. & PAN 7351 & 1550 & 9 \\
\hline 16. & 433-3A $\times$ RHA271 & 1667 & 6 \\
\hline 17. & 433-3A × CM632 & 1333 & 13 \\
\hline 18. & SUNFOLA & 1500 & 10 \\
\hline 19. & 434-1A $\times$ RHA271 & 1467 & 11 \\
\hline 20. & $432-1 \mathrm{~A} \times \mathrm{CM} 632$ & 1000 & 27 \\
\hline 21. & $432-1 \mathrm{~A} \times \mathrm{R} 694$ & 1217 & 17 \\
\hline 22. & $431-1 \mathrm{~A}-3 \times \mathrm{R} 694$ & 1050 & 24 \\
\hline 23. & 431-4A-3 × CM632 & 583 & 30 \\
\hline 24. & 431-4A-2 × RHA271 & 1083 & 22 \\
\hline 25. & $431-3 \mathrm{~A}-5 \times \mathrm{RHA} 271$ & 1133 & 20 \\
\hline 26. & $371-1 \mathrm{~A} \times \mathrm{CM} 632$ & 1000 & 27 \\
\hline 27. & 412-3A-2 $\times$ RHA271 & 1800 & 3 \\
\hline 28. & 432-2A-2 × RHA271 & 1250 & 16 \\
\hline 29. & 432-3A-2 × RHA271 & 1083 & 22 \\
\hline \multirow[t]{2}{*}{30.} & Sironko White & 1333 & 13 \\
\hline & Mean & 1354 & \\
\hline
\end{tabular}

Another constraint that we are facing is that the restorer lines that are used for crossing with female inbred parental lines are very short and early maturing. Sometimes they do not produce enough pollen during dry conditions and have also fewer branches that could produce pollen as they continue growing. This makes synchronization of flowering difficult and therefore less seed produced for testing across locations. 
As we are developing our own hybrids through collaboration with other national institutes, we are also evaluating other imported hybrids for the private seed companies in Uganda which can afford to import hybrid seed.

\section{CONCLUSION}

Uganda has a potential to start producing sunflower hybrids which are sustainable and cheaper compared with imported ones. To attain this, some bottlenecks in hybrid development have to be mitigated. In order to achieved production stability of a hybrid, high genetic purity of basic seed should be ensured in the parental lines involved in hybrid combinations. Improvement can be attained only through collaboration with other national institutes, those who are willing to share their germplasm with others.

\section{ACKNOWLEDGEMENT}

The sunflower research at Serere Agricultural Research Institute is currently being supported by the Vegetable Oil Development Project (VODP) under the Ministry of Agriculture, Animal Industry and Fisheries (MAAIF), NARO and Agricultural Productivity Enhancement Programme (APEP) for which support I am are very grateful indeed. I also acknowledge the active participation of the technician and field staff in the sunflower research programme at Serere. This paper would not have been written if I did not get the parental lines from Dr. Jerry F.Miller, USDA, North Dakota (USA), and Dr. Walter Dedio, Morden (Canada).

\section{REFERENCES}

Giriraj, K., 1998. Development of A,B and R lines for use in heterosis breeding in sunflower. In: Hybrid sunflower seed production technology, Directorate of Oilseeds Research, Rajendranagar, Hyderabad-500 030, India. pp. 9-12.

Muralidharan, V., 1998. Technologies for increasing restorer line seed production in sunflower. In: Hybrid sunflower seed production technology, Directorate of Oilseeds Research, Rajendranagar, Hyderabad-500 030, India. pp. 25-27.

Škorić, D. and Jocić, S., 2004. Achievements of sunflower breeding at IFVC in Novi Sad, Serbia and Montenegro. Proc. $16^{\text {th }}$ Int. Sunflower Conference, Fargo, North Dakota, 2004. Vol. II.

Virupakshappa, K; Ranganatha, A.R.G and Reddy, B.N., 1998. Hybrid sunflower seed production technology. Directorate of Oilseeds, Rajendranagar, Hyderabad-500 030, India. 


\title{
ALCANCES Y DIFICULTADES EN EL DESARROLLO DE HÍBRIDOS DE GIRASOL EN UGANDA
}

\author{
RESUMEN
}

Girasol (Helianthus annuus L.) se ha vuelto el cultivo oleaginoso más importante en Uganda. Las superficies de producción han tenido una subida dinámica, a partir de mediados de los años 90 . Durante los años 70 y 80 , la selección de girasol se limitaba en valoración de los híbridos importados. Ello no tenía ninguna influencia en la producción comercial. Una reciente valoración de los híbridos llevó hasta la introducción en la producción del híbrido PAN 7351 de América del Sur, que por el momento se encuentra en plena producción, y al que importa la Compañía Mukwano Seed Company. El Instituto de Investigaciones Agrícolas en Serere (SAARI), obtuvo varias líneas parentales para el desarrollo de los híbridos. Las dificultades como ramificación y fertilidad de las líneas femeninas, han condicionado un desarrollo lento de los híbridos de esas líneas parentales. No obstante, fueron creados varios cruzamientos y se obtuvieron rendimientos por encima de $2.000 \mathrm{~kg} / \mathrm{ha}$.

\section{SUCCÈS ET DIFFICULTÉS DANS LE DÉVELOPPEMENT D'HYBRIDES DE TOURNESOL EN OUGANDA}

\author{
RÉSUMÉ
}

Le tournesol (Helianthus annuus L.) est devenu la culture oléagineuse la plus importante d'Ouganda. Les surfaces de production se sont agrandies de façon spectaculaire à partir du milieu des années 90 . Au cours des années 70 et 80 , la sélection du tournesol se limitait à l'évaluation d'hybrides importés. Ceci n'avait aucun effet sur la production commerciale. Une évaluation récente des hybrides a conduit à la production de l'hybride PAN 7351 d'Afrique du Sud qui se trouve maintenant en pleine production et est importé par la firme Mukwano Seed Company. L'institut de recherches en agronomie de Serere a reçu quelques lignées parentales pour le développement d'hybrides. Des difficultés comme la ramification et la fertilité des lignées femelles ont provoqué la lenteur du développement des hybrides de ces lignées parentales. Cependant, quelques croisements ont tout de même été faits et des rendements de plus de $2,000 \mathrm{~kg} / \mathrm{ha}$ ont été atteints. L'Ouganda peut maintenant produire sa propre semence hybride. 